logos_i_ethos_2019_2_(50), s. 107-125

DOI: http://dx.doi.org/10.15633/lie.3480

Rafał Dudała

https://orcid.org/0000-0002-9942-3470

Uniwersytet Jana Kochanowskiego w Kielcach

\title{
Polisemiczny charakter zjawiska laickości i przykłady jego zastosowania we współczesnym dyskursie publicznym
}

Wielowątkowość relacji między światem „religijnym” a światem „laickim" stanowi ważną inspirację dla podejmowanej eksploracji koncepcji „laickości”, także na poziomie etymologicznym. Termin ten narodził się w XIX wieku i pochodzi od słowa lä̈c. W przestrzeni religijnej wskazuje na nieprzynależność do kleru: laik to ktoś, kto nie jest dr hab. Rafał Dudała - prezbiter diecezji kieleckiej, absolwent Wydziału $\mathrm{Hu}$ manistycznego Uniwersytetu Jana Kochanowskiego w Kielcach oraz Papieskiego Uniwersytetu Laterańskiego w Rzymie; adiunkt w Instytucie Stosunków Międzynarodowych i Polityk Publicznych UJK oraz wykładowca Wyższego Seminarium Duchownego w Kielcach. Zainteresowania: teoria polityki, system polityczny Włoch, populizm polityczny, relacja religiapolityka. duchownym. Ta dość wąska teologicznie koncepcja została potwierdzona także przez najnowsze dokumenty kościelne Kościoła katolickiego ${ }^{1}$. Z czasem jednak pojęcie ewoluuje w lä̈cque i wskazuje na tego, kto staje pod sztandarem laickości oraz wyzwala się spod wpływu konfesji, uprzywilejowując jego rolę członka społeczeństwa świeckiego (obywatelskiego). Etymologicznie „laickość”

1 Za przykład może posłużyć Dekret o apostolstwie świeckich Apostolicam actuositatem Soboru Watykańskiego II oraz Adhortacja posynodalna Jana Pawła II Christifideles laici na temat powołania i misji świeckich w Kościele i w świecie. 
pochodzi od łacińskiego laicus, który transponuje późnogreckie laïkos. Ten grecki przymiotnik odpowiada rzeczownikowi laos lub populos ${ }^{2}$.

Naukowego namysłu wymagają jednak przede wszystkim społeczno-polityczne reperkusje towarzyszące praktycznej realizacji laickości. Dlatego też podejmowane w tym celu analizy słusznie podkreślają spory wokół współczesnej recepcji zasady laickości. Ilustrują one dobitnie ryzyko nadużyć, które może przybrać zideologizowaną formę laicyzmu. Wśród przyczyn należy wskazać zarówno nieostry charakter samego pojęcia, jak i dwuznaczność w realizacji wspomnianej zasady. Pewną formą systematyzacji może okazać się propozycja przypisania wspólczesnej laickości funkcji, które miałaby spełniać w ramach toczącego się dyskursu publicznego ${ }^{3}$.

Dzięki temu sama koncepcja odkrywa swą praktyczną wartość, zwłaszcza w kontekście tych wyzwań, które wpływają zarówno na kryzys państwowości, jak i zmieniające się relacje państwo-Kościól ${ }^{4}$.

Zakreślony powyżej obszar badawczy wskazuje zarazem cel niniejszych rozważań: analiza pojęcia "laickości” wraz z tkwiącą w nim wieloznacznością. Podjęta analiza uwzględniła zarówno stanowisko

2 Por. G. Cimbalo, Laicità come strumento di educazione alla convivenza, w: Laicità e diritto, a cura di S. Canestrari, Bologna 2007, s. 269-270.

3 W tym kontekście na szczególną uwagę zasługują analizy prowadzone m.in. przez Jürgena Habermasa (koncepcja epoki postsekularnej: J. Habermas, Wierzyć i wiedzieć, „Znak” 558 (2002) nr 9, s. 8-21) czy Petera Bergera (teoria desekularyzacji: P. Berger, Sekularyzm w odwrocie, „Res Publica” 11 (1997), s. 67-74) oraz wystąpienia prezydenta Republiki Francuskiej Nicolasa Sarkozy’ego (laickość pozytywna: przemówienia w Rzymie, 20 grudnia 2007, w Riadzie, 14 stycznia 2008 oraz w Paryżu, 12 września 2008; zob. R. Dudała, La nozione della libertà religiosa nella dichiarazione „Dignitatis humanae". Una riflessione sulla società e sulla cultura contemporanea, Kielce 2017, s. 301-306).

${ }^{4} \mathrm{Na}$ te kwestie, łączone z zagadnieniem wolności religijnej, relacją państwo-Kościół czy stosunkiem polityki i religii, wskazuje szereg opracowań dostępnych także w języku polskim: G. Haarscher, Laickość: Kościół, państwo, religia, Warszawa 2004; J. Casanova, Religie publiczne w nowoczesnym świecie, tłum. T. Kunz, Kraków 2005; V. Possenti, Religia i życie publiczne. Chrześcijaństwo w dobie ponowożytnej, Warszawa 2005; M. Potz, Granice wolności religijnej. Kwestie wolności sumienia i wyznania oraz stosunku państwa do religii w Stanach Zjednoczonych Ameryki, Wrocław 2008 (Monografie Fundacji na rzecz Nauki Polskiej. Seria Humanistyczna); M. Marczewska-Rytko, Religia i polityka w globalizującym się świecie, Lublin 2010; Religia i polityka. Zarys problematyki, red. P. Burgoński, M. Gierycz, Warszawa 2014. Na uwagę zasługują także czasopisma podejmujące tę tematykę, m.in. „Politologia Religii” i „Teologia Polityczna”. 
diachroniczne, które ujmuje laickość jako rozciągnięty w czasie proces, jak i synchroniczne, pozwalające dostrzec $w$ niej jednoczesność zachodzących zjawisk. Pierwsze wsparte zostało na wynikach badań przeprowadzonych przez specjalistów z dziedziny nauk politycznych, filozoficznych, prawnych i socjologii; drugie odniesione zostało do trzech wybranych kwestii, które wskazują na ważkość funkcji do spełnienia, jakie stawia się przed koncepcją laickości.

Realizacji opisanego celu służą przyjęte dwie hipotezy badawcze:

1. Obecne wieloznaczne rozumienie laickości jest wynikiem procesu historycznego, na który miały wpływ głównie nowożytne idee polityczne i filozoficzne;

2. Laickość ma swój polisemiczny atrybut wyrażający się w przypisywanych jej współcześnie funkcjach.

W toku prowadzonej analizy dwie metody znalazły swoje szczególne zastosowanie. Po pierwsze, metoda porównawcza, odniesiona do wybranych propozycji systematyzujących zjawisko laickości. Po drugie, metoda historyczna, która, umożliwiając uchwycenie laickości jako procesu, pozwala na jego generalizującą deskrypcję.

\section{Wieloznaczność pojęcia laickości}

Nader złożona semantyka laickości bywa ujmowana w odniesieniach do licznych dyscyplin naukowych - filozofii ${ }^{5}$, teologii ${ }^{6}$, prawa ${ }^{7}$, polito$\operatorname{logii}^{8}$ czy socjologii ${ }^{9}$ - i co rusz poddawana próbom systematyzacji ${ }^{10}$.

5 Por. Laicità e filosofia, a cura di G. Miligi, G. Perazzoli, Milano-Udine 2010; F. Macioce, Una filosofia della laicità, Torino 2007; H. Seidl, Il laico davanti a Dio. Risposta filosofica al laicismo di oggi, Soveria Mannelli 2010.

6 Por. Laicità e democrazia: una questione per la teologia, a cura di L. Casula, Milano 2011.

7 Por. La laicità crocifissa? Il nodo costituzionale dei simboli religiosi nei luoghi pubblici, a cura di R. Bin, G. Brunelli, A. Pugiotto, P. Veronesi, Torino 2004.

8 Por. C. Magris, La storia non è finita. Etica, politica, laicità, Milano 2008.

9 Por. P. Donati, Oltre il multiculturalismo. La ragione relazionale per un mondo comune, RomaBari 2010; Laicità: la ricerca dell'universale nelle differenze, a cura di P. Donati, Bologna 2008.

10 Szczególnej uwagi domaga się niewątpliwie uwzględnienie odmiennych tradycji filozoficznych, bezpośrednio oddziałujących na proces kształtowania się i rozumienia laickości czy sekularyzacji 
Za przykład służyć może wypis paradygmatów dotyczących zarówno nauki o prawie, jak i historii prawa: laickość jako autonomia prawa (autonomia systemu prawnego względem sfery etyczno-religijnej); laickość jako autonomia polityczna (ograniczenie nadużyć władzy kościelnej względem władzy świeckiej, od form teokratycznych po wyznaniowe znaczone anomalną „,ingerencją"); laickość jako ograniczenie polityki (ograniczenie ingerencji władzy świeckiej we władzę religijną, od różnych form jurysdykcjonalizmu po najnowsze formy „wrogiej laickości”); laickość jako pluralizm wyznaniowy (uznanie i zagwarantowanie wolności religijnej i pluralizmu religijnego); laickość protegowana (obojętność i wyobcowanie sfery publicznej względem czynnika religijnego przez co laickość, dążąc do własnej ochrony, przeradza się w wojującą ideologię); laickość jako pluralizm polityczny (uznanie i zagwarantowanie wolności indywidualnej, a także pluralizmu kultur i tradycji oraz - co za tym idzie - odrzucenie "państwa etycznego" i każdej ideologii państwowej). Dopełnieniem powyższych wskazań teoretycznych jest odniesienie do kształtowania relacji międzyludzkich, co może wpływać na funkcjonalność określonej społeczności: laickość jako metoda, która łączy niewierzących i wierzących oraz kształtuje warunki na rzecz koegzystencji pomiędzy przeciwstawnymi wartościami czy ideami. Za kluczowe należy wówczas uznać odrzucenie konfliktogennych fundamentalizmów i dogmatycznych ograniczen ${ }^{11}$.

Wszystko to, przy uwzględnieniu przemian historycznych, sprawia, że obecnie nie sposób już mówić ani o jednej laickości, ani też o jednorodnym jej rozumieniu i zastosowaniu do konkretnych, odmiennych kulturowo warunków ${ }^{12}$. Na ten walor polisemiczny laickości wskazali sygnatariusze Międzynarodowej deklaracji o laickości (9 grudnia 2005) dokumentu podpisanego przez dwustu pięćdziesięciu intelektualistów

w Europie. Zob. P. Mazanka, Źródła sekularyzacji i sekularyzmu w kulturze europejskiej, Warszawa 2003; G. Dalla Torre, Europa. Quale laicità, Cinisello Balsamo 2007; P. Giovanetti, Europa. Religioni. Laicità. Dieci interviste, Milano 2007.

11 Por. A. Barbera, Il cammino della laicità, w: Laicità e diritto, a cura di S. Canestrari, Bologna 2007, s. 33-91.

12 Por. G. Dalla Torre, Le „laicità” e la „laicità”, w: Laicità cristiana, a cura di F. D’Agostino, Cinisello Balsamo 2007, s. 17-38; M. R. D’Uggento, Quale laicità, Trento 2009. 
z trzydziestu krajów i przedstawionego Senatowi Republiki Francuskiej: „Proces laicyzacji ma miejsce, gdy Państwo nie jest już legitymizowane przez religię bądź określoną szkołę myślenia, gdy wszyscy obywatele są w stanie spokojnie deliberować, z równymi prawami i godnością, i kiedy mogą sprawować, w oparciu o własną suwerenność, władzę polityczną [...]. Dlatego elementy laickości z konieczności pojawiają się w każdym społeczeństwie, które chce zharmonizować stosunki społeczne naznaczone interesami i wielorakimi koncepcjami moralnymi lub religijnymi [...]. Laickość nie jest prerogatywą żadnej kultury, żadnego narodu, żadnego kontynentu. Może istnieć w sytuacjach, w których termin ten nie był tradycyjnie używany"13.

Wnikliwą analizę heterogeniczności laickości przedstawił Jean Baubérot, francuski socjolog, uznawany za twórcę socjologii laickości. W dziele Les laïcités dans le monde (2007) rozróżnia on trzy „progi” w procesie laicyzacji, określane „zmianami zygzakowymi”. Utrzymuje, iż nie istnieje jedna laickość, ale wiele laickości w świecie, które są zróżnicowane w zależności od kształtujących je procesów historycznych czy podwalin filozoficznych. Ponadto laickości odpowiadają różnym rodzajom rzeczywistości społecznej, kulturowej, politycznej i religijnej ${ }^{14}$. W celu ich oceny należy odwołać się do wskaźników funkcjonalnych ${ }^{15}$.

13 La Déclaration universelle sur la laïcité au XXIe siècle, „Le Monde” 10.12.2005. Oryginalny tekst Deklaracji: https://www.lemonde.fr/idees/article/2005/12/09/declaration-universelle-sur-la-laicite-au-xxie-siecle_719649_3232.html (2.02.2019). Cyt. za: J. Baubérot, Le tante laicità nel mondo. Per una geopolitica della laicità, perchè essa non è un assoluto fuori dal tempo, ma il frutto di processi storici e di fondamenti filosofici differenti, Roma 2008, s. 7.

14 Przykładem owego zróżnicowania są liczne modele relacji państwo-Kościół obowiązujące w ramach systemów politycznych (konfesyjne, separacyjne, mieszane oraz - niekiedy wyróżniane oddzielnie - ateistyczne). Por. V. Prieto, Diritto dei rapporti tra Chiesa e società civile, Roma 2008. Znaczący wpływ mają na to odmienne tradycje religijne, których formułowana doktryna pozostaje w ścisłym związku z realizowanym w danym państwie modelem laickości. Zob. Relacje religii i polityki w ujęciu głównych religii, w: Religia i polityka. Zarys problematyki, red. P. Burgoński, M. Gierycz, Warszawa 2014, s. 26-199; M. R. Piccinni, Profili di tutela della libertà religiosa nelle Costituzioni dei Paesi della riva sud del Mediterraneo e nelle Dichiarazioni arabo-islamiche sui Diritti dell'Uomo, https://riviste.unimi.it/index.php/statoechiese/article/view/922 (3.02.2019); S. Ceccanti, Una libertà comparata. Libertà religiosa, fondamentalismi e società multietniche, Bologna 2000.

15 Zob. J. Baubérot, Le tante laicità nel mondo, dz. cyt., s. 9. 
Już w okresie wstępnym, prehistorycznym, pojawiają się elementy zapowiadające przyszłą laickość, znacznie starsze aniżeli zachodnia nowożytność ${ }^{16}$. W Europie za przełomowe wydarzenie należy uznać przyjęcie chrześcijaństwa przez imperatorów rzymskich w IV wieku i rozwój idei christianitas, która z czasem uległa załamaniu. Obowiązującą wówczas koncepcją był model nowoczesnego państwa, które zakłada konfigurację teologiczno-polityczną z absolutyzmem oraz teorię suwerenności króla w sprawach duchowych i ziemskich. Za moment odejścia od powyższego modelu (prehistorii) i początku okresu zwanego historią laickości uznaje się „pierwszą mondializację, tj. koniec XVIII i początek XIX wieku"

Okres rozwoju idei laickości zwykle był określony dwoma wymiarami - filozoficznym i politycznym. Na pierwszy wpłynęły przede wszystkim myśl i dzieła Johna Locke’a (postulat separacji), Voltaire’a (nietolerancja religijna) i Jeana-Jacquesa Rousseau (religia świecka). Drugi został naznaczony przez „despotyzm oświecony” i jego reprezentantów tworzących formę autorytarnej laicyzacji. Charakteryzując pierwszy próg laicyzacji, należy podkreślić, że państwo przestało zapewniać „zbawienie” własnym obywatelom, skupiało się na ich doczesnych interesach oraz wskazywało na własną niekompetencję w sprawach religijnych. Pojawiła się laicyzacja suwerenności oraz dysocjacja pomiędzy przynależnością religijną a obywatelstwem. Towarzyszyły temu trzy faktory: fragmentaryzacja instytucjonalna, legitymizacja społeczna oraz uznanie pluralizmu religijnego (często ograniczonego) przez politykę ${ }^{18}$.

Naczelnym motywem prowadzącym do drugiego progu laicyzacji była idea szczęścia, która, według założeń oświeceniowego deizmu, znajduje się w rękach ludzi. Wspierała go „druga mondializacja” i towarzyszące

16 Do takich przykładów można zaliczyć antyklerykalizm buddyjski, którego uniwersalizm pochodzi z faktu, iż formuła religijna zarządzania relacjami sacrum-profanum podlega ciągłej kontestacji. Innym przykładem są trzy formy relacji między religią a polityką w tradycji islamu sunnickiego: jedność w osobie kalifa, relatywizacja religijnej władzy na terenie sułtanatu oraz praktyka idżtihad (ijtihâd), która służy kontekstualizacji i modernizacji szariatu (sharia). Por. J. Baubérot, Le tante laicità nel mondo, dz. cyt., s. 14; T. Ramadan, Islam e libertà, Torino 2008, s. 108-114.

17 Zob. J. Baubérot, Le tante laicità nel mondo, dz. cyt., s. 17-18.

18 Zob. J. Baubérot, Le tante laicità nel mondo, dz. cyt., s. 46-48. 
jej wydarzenia: walki niepodległościowe w Ameryce Łacińskiej, rozwój koncepcji sekularyzacji i laicyzacji, oddzielenie Kościołów i szkół oraz ekspansja kolonialna, zwłaszcza świata muzułmańskiego. Okres ten znaczony był trzema charakterystykami: religia, głównie wskutek autonomizacji szkolnictwa, stała się instytucją społecznie fakultatywną; potrzeby religijne utraciły walor obiektywnych, stając się „sprawą prywatną", osobistym wyborem; praktyka wolności sumienia została oparta na podstawowym warunku dysocjacji między przynależnością cywilną a religijną ${ }^{19}$.

Wiek XIX to czas tworzenia się filozoficznych fundamentów ateizmu i rozwoju nauk. Sprzyjało to procesowi trzeciego progu, czyniąc współczesne społeczeństwa bardziej zsekularyzowanymi, choć niekoniecznie laickimi. Postępujący proces laicyzacji przyjął formę trojaką: dezinstytucjonalizacji dotyczącej tych podmiotów, które zdestabilizowały struktury religijne, stając się krzewicielami symboliki laickiej; kryzysu socjalizacji moralnej opisanej naczelną zasadą „realizacji siebie”; nowej pluralistycznej rzeczywistości tworzącej wierzenia „bez przynależności” i na sposób synkretyczny ${ }^{20}$.

Zdaniem Baubérota obserwowane procesy doprowadziły do zmian geopolitycznych laickości, kształtowanej przez trzy determinanty: dekolonizację pozwalającą wielu krajom wyjść spod panowania Zachodu; komunizm państwowy reprezentujący formę laicyzacji totalitarnej,

19 Zob. J. Baubérot, Le tante laicità nel mondo, dz. cyt., s. 62-63.

20 Zob. J. Baubérot, Le tante laicità nel mondo, dz. cyt., s. 102-104. Wprawdzie laicyzacja zniosła średniowieczną dystynkcję pomiędzy władzą doczesną a władzą duchową, jednak władza polityczna nie porzuciła całkowicie wszystkich wymiarów religijnych. Przykładowo monizm ideologiczny, obecny w religiach świeckich, stał się dominujący w państwie totalitarnym i definiowany jest jako religia świecka lub religia polityczna. Oba terminy (modele) były analizowane w dziełach wielu wybitnych myślicieli, takich jak Ernst Kantorowicz, Hans Blumenberg, Raymond Aron, Jules Monnerot, Karl Polanyi, Eric Voegelin, Giovanni Gentile czy Hannah Arendt. Por. E. Gentile, Le religioni della politica: fra democrazie e totalitarismi, Roma-Bari 2001, s. 25-67. W tym też kontekście pojawia się rozpowszechnione przez Roberta Bellaha pojęcie civil religion: R. Bellah, Civil Religion in America. „Daedalus Journal of the American Academy of Arts and Science” 1 (1967), s. 1-21; D. L. Adams, K. Schurb, The Anonymous God: The Church Confronts Civil Religion and American Society, St. Louis Missouri 2004. 
niepozwalający na wyrażenie się laickości demokratycznej, przez co została ona utożsamiona $\mathrm{z}$ oficjalnym ateizmem; laickość związaną z rozwojem państwa narodowego i jego wyzwolenia się spod jakiegokolwiek wpływu religijnego ${ }^{21}$.

Z koncepcją Baubérota współbrzmi propozycja Pierpaola Donatiego, podkreślająca historyczne uwarunkowania polisemicznego charakteru omawianego pojęcia. Włoski socjolog i filozof wskazuje na trzy podstawowe znaczenia terminu "laickość”, które, choć do dziś używane, to jednak rzadko występują w „czystym” znaczeniu. Laickość $w$ sensie przednowoczesnym odnosi się do ludu (laikòs), czyli charakteryzuje tego, kto nie przynależy do kleru, nie jest wtajemniczony, nie nosi szczególnych oznak i działa na podstawie rozróżnienia między tym, co boskie i cesarskie. Laickość w sensie nowoczesnym jest wyrazem myślenia i działania, opartym na prymacie rozumu autonomicznego, aprobacie dla sekularyzacji i uznaniu dla jednostki jako takiej, co prowadzi do neutralności wobec jakiejkolwiek religii. Laickość w sensie ponowoczesnym to mentalność świecka (acz nie zeświecczona), która wyraża relację między wiarą a rozumem bez uprzywilejowywania którejkolwiek ze stron: rozróżnia ich wzajemne strefy wpływów oraz łączy je między sobą tam, gdzie jest to konieczne i możliwe ${ }^{22}$.

Na silny związek idei laickości z kulturą chrześcijańską wskazuje Giuseppe Dalla Torre. Zaznacza przy tym, że dążenie do świeckiego państwa, które kiełkowało i rozwijało się w środowiskach starożytnego chrześcijaństwa, napotykało na trudności co do sposobów afirmacji także ze względu na tendencję nowoczesnego państwa do wzorowania się na instytucji kościelnej. Wskazując zaś na wieloznaczność laickości, odnosi ją do czterech paradygmatów.

Pierwszy z nich to polityczno-prawna zasada suwerenności, którą włoski teoretyk prawa określa mianem „kamienia węgielnego

21 Zob. J. Baubérot, Le tante laicità nel mondo, dz. cyt., s. 80-81.

22 Zob. P. Donati, Oltre il multiculturalismo. La ragione relazionale per un mondo comune, RomaBari 2010, s. 70. 
współczesnego prawa publicznego i konstytucyjnego"23. Definiowana w sensie szerszym zasada ta służy ukazaniu rządzącej władzy ostatecznej instancji w społeczeństwie politycznym i, co za tym idzie, odróżnienia jej od innych stowarzyszeń, których organizacja nie określa władzy jako najwyższej, nieograniczonej i niezależnej ${ }^{24}$. Suwerenność jako prymat władzy politycznej nad każdą inną władzą znacznie utrudnia realizację autentycznej laickości, z uwagi na dwa różne porządki odniesień. Porządek faktyczny dotyczy suwerenności przyznającej kompetencje państwu także co do historycznego, społecznego i publicznego wyrażania religii. W konsekwencji państwo przestaje jawić się jako bezstronne wobec religii: może to przybierać formę konfesjonalizacji, ignorancji spychającej w prywatny obszar indywidualnego sumienia bądź jawnego zwalczania faktu religijnego. Tymczasem założeniem laickości państwa jest zasada jego niekompetencji w materii religijnej. Porządek strukturalny prowadzi do nieuchronnego utożsamienia legalności z legitymizacją, działania według prawa $\mathrm{z}$ działaniem według sprawiedliwości. $\mathrm{W}$ ten sposób naruszana jest obiektywna granica między władzą polityczną a prawem naturalnym. Tak rozumiana suwerenność przeradza się we władzę absolutną: państwo porzuca świeckie pozycje i od uznania prawdy obiektywnej, uniwersalnej i niezmiennej jest skłonne przejść do „panteonu wyznań religijnych i etycznych, aby objąć jedną z nich”25. W efekcie także wybór neutralności przestaje być neutralny, gdyż oznacza obranie jednej orientacji kulturowej pośród innych. Reasumując, należy zauważyć, że afirmacja laickości przebiega poprzez uznanie idei suwerenności jako atrybutu państwa. Winna to być raczej idea nie absolutna, lecz względna, która odnajduje obiektywne ograniczenia ${ }^{26}$.

Innym z elementów kształtujących laickość jest postawa „favor religionis". Wyrażenie to nie stanowi opisu stosunku do religii jako miary tolerancji czy nietolerancji wobec innych. Przeciwnie, jest to postawa

${ }^{23}$ G. Dalla Torre, Le „laicità" e la „laicità", dz. cyt., s. 22.

24 Por. N. Matteucci, Sovranità, w: N. Bobbio, N. Matteucci, G. Pasquino, Il dizionario di politica, Torino 2007, s. 909.

25 Por. G. Dalla Torre, Le „laicità” e la „laicità”, dz. cyt., s. 22-23.

26 Por. G. Dalla Torre, Le „laicità" e la „laicità”, dz. cyt., s. 22-25. 
państwa i jego systemu politycznego odniesiona do uznania wartości religijnych za pozytywne, zasługujące na ochronę prawną, która, wykraczając poza granice zwykłej legalności, zostałaby uznana za kategorię prawa do wolności (wolność religijna). W ramach tej koncepcji przyjmuje się dwa istotne założenia. $Z$ jednej strony mowa jest o koncepcji „względnej suwerenności”, która podkreśla brak kompetencji państwa do wskazywania wyborów w materii religijnej, domagając się jednocześnie porzucenia pozycji laicystycznych. Z drugiej zaś - uznanie publicznego charakteru samej religii, bez utożsamiania jej z zaangażowaniem politycznym. Dzięki przywołaniu koncepcji laickości religia przejawia się i wyraża publicznie, współtworząc tym samym relacje między państwem a społeczeństwem obywatelskim ${ }^{27}$.

Kolejne $\mathrm{z}$ odniesień stanowi relacja między wolnością religijną a równością. Prawo do wolności religijnej, stanowiąc conditio sine qua non istnienia laickości, winno być rozumiane w dwojakim sensie. Znaczenie negatywne wyraża się poprzez gwarancję ochrony przed zewnętrznym przymusem w materii religijnej, bez względu na jego pochodzenie. Pozytywne zaś znaczenie to możliwość wyrażania publicznie przekonań sumienia, dając temu świadectwo zarówno poprzez akty kultu, jak i inne postawy ważne dla religii. Towarzyszy temu realizowana w dwóch wymiarach zasada równości. W sensie formalnym postuluje ona poszanowanie obowiązujących norm oraz nienadużywanie władzy dyskrecjonalnej w sytuacji różnorodności religijnej. Nierzadko prowadzi to do dylematu dotyczącego pozycji różnorakich wartości w społeczeństwie ${ }^{28}$. Natomiast w sensie materialnym równość zakłada włączenie instytucji publicznych w respektowanie obowiązku znoszenia przeszkód uniemożliwiających korzystanie ze swobód i praw. Dzięki nim państwo jest zaangażowane w tworzenie warunków pozwalających doświadczyć w pełni -

27 Por. G. Dalla Torre, Le „laicità" e la „laicità”, dz. cyt., s. 25-30.

28 Przywołując tzw. wspólne minimum etyczne, które dziś często jest efektem mediacji, Dalla Torre przypomina o doniosłym znaczeniu sprawiedliwości: ponieważ „świeckość prawa wyraża się $\mathrm{w}$ wierności ustawodawcy, a więc w zgodności z normą pozytywną, wobec jedynej wartości etycznej, która naprawdę wiąże tworzenie prawa: sprawiedliwość" (G. Dalla Torre, Le "laicità" e la "laicità", dz. cyt., s. 33). 
osobom wierzącym oraz niewierzącym - wolności religijnej w sposób indywidualny, kolektywny i instytucjonalny ${ }^{29}$.

Ostatnim paradygmatem dotyczącym laickości jest zasada separacji między państwem a Kościołem, rozumiana jako „dystynkcja”. Różnicując między sobą porządek własny państwa i porządek własny pojedynczych wyznań religijnych, owa dystynkcja pozostaje naczelnym postulatem laickości, gwarantowanej zarówno przez krajowe konstytucje, jak i konkordaty podpisywane z Kościołem katolickim. Te zapisy czynią religię „widzialną” społecznie: ich brak - twierdzi Dalla Torre - skutkowałby ograniczeniem religii do sfery prywatnej, postawieniem jej poza wymiarem publicznym i uczynieniem prawnie nierozpoznaną. Kwestią dyskusji pozostaje natomiast charakter publicznej manifestacji religii przy jednoczesnej trosce o nieingerowanie w porządek właściwy państwu. Wspomniana dystynkcja nie oznacza zatem ani zmieszania, ani też wzajemnej ignorancji ${ }^{30}$. Relacje pomiędzy państwem a wyznaniami religijnymi, realizowane na mocy różnorakich regulacji legislacyjnych, winny wzmacniać porządek prawny odpowiedni do zagwarantowania tożsamości każdej obecnej religii, wspierając tym samym ich publiczną nie-polityczną rolę ${ }^{31}$.

\section{Funkcje laickości}

Wyrazem polisemicznego charakteru laickości są pojawiające się w dyskursie publicznym napięcia między wiarą i rozumem czy między polityką i religią. Zauważa je Sergio Belardinelli, podkreślając ich doniosłość w rozwijającym się na Zachodzie modelu laickości. Wśród nich

29 G. Dalla Torre, Le „laicità” e la „laicità”, dz. cyt., s. 30-34.

30 Warty podkreślenia jest fakt, że postulowana „dystynkcja” stanowi ważną część obowiązującego nauczania Kościoła katolickiego: „Wspólnota polityczna i Kościół są w swoich dziedzinach od siebie niezależne i autonomiczne. Obydwie jednak wspólnoty, choć z różnego tytułu, służą powołaniu jednostkowemu i społecznemu tych samych ludzi. Tym skuteczniej będą wykonywać tę służbę dla dobra wszystkich, im lepiej będą rozwijać między sobą zdrową współpracę, uwzględniając także okoliczności miejsca i czasu" (Konstytucja duszpasterska o Kościele w świecie współczesnym Gaudium et spes, w: Sobór Watykański II, Konstytucje. Dekrety. Deklaracje, Poznań 2002, s. 76).

31 Zob. G. Dalla Torre, Le „laicità" e la „laicità", dz. cyt., s. 34-37. 
wymienia „rozróżnienie między religią a polityką, pluralizmem a wolnością instytucji liberalno-demokratycznych, świadomość (zwłaszcza ze strony niewierzących), że wszystko to rozwinęło się dzięki dużemu wkładowi wiary chrześcijańskiej, a także świadomość (zwłaszcza ze strony wierzących), że w społeczeństwie pluralistycznym trzeba umieć przekazywać prawdy wiary, unikając pretensji do tego, by stały się one wiążące dla wszystkich bez zgody choćby większości zainteresowanych" ${ }^{32}$.

Formą wyjścia naprzeciw wspomnianym napięciom jest próba systematyzacji zjawiska laickości. Przykładem realizacji tego postulatu jest odniesienie laickości do współczesnych wyzwań, które wpływają zarówno na kryzys państwowości, jak i zmieniające się relacje państwoKościół. Dla potrzeb niniejszego opracowania, trzy zostały uznane za reprezentatywne: relatywizm, publiczna rola religii oraz prawda.

Słuszny postulat podtrzymywania otwartego charakteru współczesnego społeczeństwa coraz wyraźniej znaczony jest wielością stanowisk względem relatywizmu. W poszukiwaniu koniecznego porozumienia warto przywołać koncepcję laickości i jej powszechnej akceptacji w odniesieniu do dwóch podstawowych założeń. Po pierwsze - społeczeństwo jest otwarte, ponieważ jest laickie (świeckie), po drugie - wspomnianego otwarcia nie należy interpretować jako indyferentyzmu wobec wszystkiego. W ten sposób laickość odsłania swoje prawdziwe korzenie oraz pozwala na wyjście z jej relatywistycznego samorozumienia.

W tym kontekście pojawia się istotny problem prawno-politycznej refleksji na temat neutralności religijnej państwa i towarzyszącego jej ryzyka „religii politycznej”. Ma to związek z próbami wykluczania treści religijnych z dyskursu publicznego. Kreowany w ten sposób model prowadzi do „sakralizacji systemu politycznego opartego na nieodwołalnym monopolu władzy, na ideologicznym monizmie, narzuconym i bezwarunkowym podporządkowaniu jednostki i wspólnoty jej kodeksowi przykazań. Porządek ten ma na celu przeniknięcie każdego aspektu

32 S. Belardinelli, Laltro Illuminismo. Politica, religione e funzione pubblica della verità, Soveria Mannelli 2009, s. 54-55. 
życia, indywidualnego i zbiorowego"33. Odmienną propozycją mogłaby stać się kultura polityczna, której tożsamość podkreśla charakter dialogiczny. Pozostaje ona otwarta na to, co „inne” i w ten sposób tworzy zręby laickości, która nie ma nic wspólnego z sakralizacją systemu politycznego. Pozwala zachować nienaruszalność praw człowieka, w tym wolność religijną, docenia znaczenie kultury oraz instytucji gwarantujących ideowy pluralizm, polityczne współzawodnictwo, nieideologiczne działanie władzy oraz możliwość odwołania jej środkami pokojowymi i konstytucyjnymi ${ }^{34}$.

Kolejną z funkcji laickość ma do zrealizowania względem publicznej roli religii, gdzie kluczową rolę do spełnienia ma państwo. Tworząc polityczne i prawne gwarancje pokojowej koegzystencji obywateli o różnej przynależności religijnej i wyznaniowej, państwo jako pierwsze powinno realizować zasadę laickości. Jednak postulowany pokojowy pluralizm pomiędzy wyznaniami religijnymi nie może być zagwarantowany w dwóch przypadkach: gdy państwo pozostawałoby konfesyjne bądź obrało pozycje laicystyczne, spychając wszystkie wyznania religijne do sfery prywatnej ${ }^{35}$. Jednak wybór prywatyzacji wszystkich religii jako sposób rozwiązania potencjalnych napięć byłby sprzeczny z zasadą wolności religijnej, jak i samą laickością państwa. Inna z propozycji mówi o poszanowaniu suwerenności państwa konstytucyjnego, czemu towarzyszy uznanie dla publicznej roli religii i jej wkładu w rozwój wspólnoty politycznej i społeczeństwa obywatelskiego ${ }^{36}$.

Ostatnią z wybranych kwestii, mającą swoje miejsce w toczącym się dyskursie publicznym, jest spór wokół rozumienia prawdy, jej przekazywania i sposobów ochrony przed ideologizacją. Również w tym

33 E. Gentile, Le religioni della politica, dz. cyt., s. XIII-XIV.

34 Por. S. Belardinelli, Laltro Illuminismo, dz. cyt., s. 57-61.

35 Por. S. Belardinelli, Láltro Illuminismo, dz. cyt., s. 61. Za przełom w tej materii należy uznać epokę oświecenia, która w kwestii rozróżnienia sfery religijnej od sfery politycznej stworzyła dwa modele: frankofoński (laïcité) oraz anglosaski (religious freedom). Por. R. Dudała, La nozione della libertà religiosa nella dichiarazione „Dignitatis humanae”..., dz. cyt., s. 285-312; R. Rémond, Religion and Society in Modern Europe, Malden M.A. 1999.

36 Por. G. Crepaldi, Il cattolico in politica. Manuale per la ripresa, Siena 2010. 
względzie koncepcja laickości może okazać się pomocna. Jak zauważa Jürgen Habermas, „konstytucyjne państwo demokratyczne na ogół reprezentuje formę rządu domagającą się, by tak rzec, wrażliwości na prawdę"37. Implikuje to nie tylko jej walor poznawczy, ale także świadomość nadużyć, które mogą towarzyszyć jej odkrywaniu. Dlatego też toczony w demokratycznej przestrzeni publicznej „spór o prawdę” winien znaleźć swoje oparcie w zasadzie sformułowanej przez Gian Enrica Rusconiego: „wszyscy obywatele, wierzący i niewierzący, wymieniają swoje argumenty i uruchamiają procedury podejmowania decyzji na podstawie porozumienia, nie pytając samych siebie autorytatywnie o powody własnych prawd wiary lub swoich przekonań w ogóle. Liczy się wzajemna perswazja i lojalne przestrzeganie procedur"38.

\section{Podsumowanie}

Podjęta analiza potwierdza bezpośredni wpływ przemian historycznych na proces laickości, zakres jego oddziaływania oraz trwałość zrodzonych w ich wyniku modeli. Ponadto laickość, pozostając zjawiskiem na wskroś współczesnym, realizuje się poprzez szereg funkcji, ważnych w kontekście sporów wokół zagadnienia relatywizmu, publicznego miejsca religii czy rozumienia prawdy. Postawione we wstępie hipotezy, choć potwierdzone w toku badań, nie wyczerpują jednak ani złożoności omawianego zjawiska, ani też skali oddziaływania trwającego wciąż procesu.

Otóż postulowana i realizowana w systemie demokratycznym laickość powinna wspierać własne odniesienie do podstawowych wartości, tak świeckich, jak religijnych, nade wszystko na ważkości argumentów, wzajemnej perswazji oraz procedurach podejmowania decyzji opartych na konsensusie. By jednak móc uwzględnić wszystkie tak zróżnicowane elementy demokratycznego porządku, potrzebny jest etos, który okaże się właściwą inspiracją do ich przestrzegania. Ponadto, uwzględniając

37 J. Habermas, Tra scienza e fede, Roma-Bari 2005, s. 47.

38 G. E. Rusconi, Come se Dio non ci fosse. I laici, i cattolici e la democrazia, Torino 2000, s. 7. 
różnicę między trafnością argumentów a procedurami, na mocy których stają się one społecznie wiążące dla wszystkich, wspomniany etos zabezpiecza prawa mniejszości w danej społeczności. Przyczynia się także do wzrostu cnót i poszanowania swobód obywatelskich. Tak więc, parafrazując znane dictum Ernsta-Wolfganga Böckenfördego, można stwierdzić, że powyższe odniesienia to konieczne warunki dla istnienia państwa laickiego, liberalnego i demokratycznego, których samo państwo nie jest w stanie zagwarantować ${ }^{39}$. Tym samym niemiecki prawnik i filozof wskazuje na aksjologiczną podwalinę demokratycznego systemu, którego zasadą działania jest zdrowa laickość. I choć nierzadko owa podwalina bywa przedmiotem krytyki w ramach obecnej debaty publicznej, należy jednak mieć na uwadze ryzyko przejścia współczesnego modelu demokracji od bycia "prawdziwym” do bycia „akceptowanym”.

\section{Bibliografia}

Adams D. L., Schurb K., The Anonymous God: The Church Confronts Civil Religion and American Society, St. Louis Missouri 2004.

Barbera A., Il cammino della laicità, w: Laicità e diritto, a cura di S. Canestrari, Bologna 2007, s. 33-91.

Baubérot J., Le tante laicità nel mondo. Per una geopolitica della laicità, perchè essa non è un assoluto fuori dal tempo, ma il frutto di processi storici e di fondamenti filosofici differenti, Roma 2008.

Belardinelli S., Laltro Illuminismo. Politica, religione e funzione pubblica della verità, Soveria Mannelli 2009.

39 Formuła ta, użyta po raz pierwszy w 1967 roku (Die Entstehung des Staates als Vorgang der Säkularisation, w: Säkularisation und Utopie. Ebracher Studien. Enst Forsthoff zum65. Geburtsstag, Stuttgart 1967, dostępne wydanie: Die Entstehung des Staates als Vorgang der Säkularisation, w: Recht, Staat, Freiheit. Studien zur Rechtsphilosophie, Staatstheorie und rirfassungsgeschichte, Suhrkamp, Frankfurt am Main 1991, s. 92-114), wielokrotnie była przywoływana przez samego autora, dosłownie bądź z pewnymi zmianami. Zob. G. E. Rusconi, Come se Dio non ci fosse, dz. cyt., s. 121125; E.-W. Böckenförde, Wolność - państwo - Kościót, Kraków 1994, s. 23-44. 
Bellah R., Civil Religion in America, „Daedalus Journal of the American Academy of Arts and Science" 1 (1967), s. 1-21.

Berger P., Sekularyzm w odwrocie, „Res Publica” 11 (1997), s. 67-74.

Böckenförde E.-W., Wolność - państwo - Kościót, tłum. P. Kaczorowski, G. Sowiński, Kraków 2004.

Casanova J., Religie publiczne w nowoczesnym świecie, tłum. T. Kunz, Kraków 2005.

Ceccanti S., Una libertà comparata. Libertà religiosa, fondamentalismi e società multietniche, Bologna 2000.

Cimbalo G., Laicità come strumento di educazione alla convivenza, w: S. Canestrari, Laicità e diritto, Bologna 2007, s. 269-313.

Crepaldi G., Il cattolico in politica. Manuale per la ripresa, Siena 2010.

D’Uggento M. R., Quale laicità, Trento 2009.

Dalla Torre G., Europa. Quale laicità, Cinisello Balsamo 2007.

Dalla Torre G., Le „laicità" e la ,laicità", w: Laicità cristiana, a cura di F. D’Agostino, Cinisello Balsamo 2007, s. 17-38.

La Déclaration universelle sur la laïcité au XXIe siècle, „Le Monde” 10.12.2005. www.lemonde.fr/idees/article_interactif/2005/12/09/declaration-universelle-sur-la-laicite-au-xxie-siecle_718769_3232.html (2.02.2019).

Donati P., Oltre il multiculturalismo. La ragione relazionale per un mondo comune, RomaBari 2010.

Dudała R., La nozione della libertà religiosa nella dichiarazione „Dignitatis humanae”. Una riflessione sulla società e sulla cultura contemporanea, Kielce 2017.

Gentile E., Le religioni della politica: fra democrazie e totalitarismi, Roma-Bari 2001.

Giovanetti P., Europa. Religioni. Laicità. Dieci interviste, Milano 2007.

Haarscher G., Laickość: Kościół, państwo, religia, tłum. E. Burska, Warszawa 2004.

Habermas J., Tra scienza e fede, Roma-Bari 2005.

Habermas J., Wierzyć i wiedzieć, „Znak” 558 (2002) nr 9, s. 8-21.

Konstytucja duszpasterska o Kościele w świecie współczesnym „Gaudium et spes”, w: Sobór

Watykański II, Konstytucje. Dekrety. Deklaracje, Poznań 2002.

La laicità crocifissa? Il nodo costituzionale dei simboli religiosi nei luoghi pubblici, a cura di R. Bin, G. Brunelli, A. Pugiotto, P. Veronesi, Torino 2004.

Laicità e democrazia: una questione per la teologia, a cura di L. Casula, Milano 2011.

Laicità e filosofia, a cura di G. Miligi, G. Perazzoli, Milano-Udine 2010.

Laicità: la ricerca dell'universale nelle differenze, a cura di P. Donati, Bologna 2008. 
Macioce F., Una filosofia della laicità, Torino 2007.

Magris C., La storia non è finita. Etica, politica, laicità, Milano 2008.

Marczewska-Rytko M., Religia i polityka w globalizującym się w świecie, Lublin 2010.

Matteucci N., Sovranità, w: N. Bobbio, N. Matteucci, G. Pasquino, Il dizionario di politica, Torino 2007, s. 909.

Mazanka P., Źródła sekularyzacji i sekularyzmu w kulturze europejskiej, Warszawa 2003.

Piccinni M. R., Profili di tutela della libertà religiosa nelle Costituzioni dei Paesi della riva sud del Mediterraneo e nelle Dichiarazioni arabo-islamiche sui Diritti dell'Uomo, https:// riviste.unimi.it/index.php/statoechiese/article/view/922 (3.02.2019).

Possenti V., Religia i życie publiczne. Chrześcijaństwo w dobie ponowożytnej, Warszawa 2005.

Potz M., Granice wolności religijnej. Kwestie wolności sumienia i wyznania oraz stosunku państwa do religii w Stanach Zjednoczonych Ameryki, Wrocław 2008 (Monografie Fundacji na rzecz Nauki Polskiej. Seria Humanistyczna).

Prieto V., Diritto dei rapporti tra Chiesa e società civile, Roma 2008.

Ramadan T., Islam e libertà, Torino 2008.

Religia i polityka. Zarys problematyki, red. P. Burgoński, M. Gierycz, Warszawa 2005.

Rémond R., Religion and Society in Modern Europe, Malden M.A. 1999.

Rusconi G. E., Come se Dio non ci fosse. I laici, i cattolici e la democrazia, Torino 2000.

Seidl H., Il laico davanti a Dio. Risposta filosofica al laicismo di oggi, Soveria Mannelli 2010.

\section{Abstrakt}

\section{Polisemiczny charakter zjawiska laickości i przykłady jego zastosowania we współczesnym dyskursie publicznym}

Przeprowadzona analiza przywołuje polisemiczny charakter pojęcia laickości, na co wpływ miały nowożytne idee polityczne i filozoficzne. Określone to zostało dwoma stanowiskami: diachronicznym, które ujmuje laickość jako rozciągnięty w czasie proces, oraz synchronicznym, które pozwala dostrzec w niej jednoczesność zachodzących zjawisk. W ten sposób koncepcja laickości odsłania swą praktyczną wartość w odniesieniu do wyzwań dotyczących zarówno kryzysu państwowości, jak i zmieniających się relacji państwo-Kościół. Wartość tę potwierdza miejsce, jakie w badaniach nad laickością zajmują zasady suwerenności, równości czy separacji. W konsekwencji realizowana w systemie 
demokratycznym zasada laickości opiera własne odniesienie do podstawowych wartości na merytorycznej argumentacji, wzajemnej perswazji oraz konsensusie jako procedurze podejmowania decyzji.

W stosunku do pierwszego stanowiska analiza przywołuje badania przeprowadzone przez specjalistów z dziedziny nauk politycznych, filozoficznych, prawnych i socjologicznych. Natomiast drugie odniesione zostało do trzech wybranych kwestii, które określają funkcje laickości: relatywizmu, publicznej roli religii oraz prawdy.

\section{Słowa kluczowe}

laickość, proces vs. zjawisko laicyzacji, religia w sferze publicznej, stosunki religiapolityka, relacje państwo-Kościół

\section{Abstract \\ The polysemic nature of the phenomenon of laicism and examples of its use in contemporary public discourse}

The analysis evokes the polysemous character of the concept of laicism, which was influenced by modern political and philosophical ideas. Two positions have determined this: a diachronic one encompasses laicism as a process extended in time, and a synchronous one allows one to perceive the simultaneity of phenomena. Thus, the concept itself reveals its practical value, especially in the context of these challenges, which affect both the state crisis and the changing relationship between the State and the Church. This value is confirmed by an important place in the secular research that is based on the principles of sovereignty, equality and separation. Thus, laicism postulated and implemented in the democratic system and its reference to fundamental values should support, above all, the importance of arguments, mutual persuasion and decision-making procedures based on consensus. In relation to the first position, the analysis refers to research carried out by specialists in the fields of political, philosophical, legal and sociological sciences. The second one, however, referred to three selected issues that define the functions of laicism: relativism, the public role of religion and truth. 
Polisemiczny charakter zjawiska laickości...

\section{Keywords}

laicism; process vs. the phenomenon of laicism; religion in the public sphere; relations religion-politics; relations State-Church 